\title{
Variability of In-Situ Plant Species Effects on Microclimatic Modification in Urban Open Spaces of Nairobi, Kenya
}

\author{
Sharon Anyango Onyango ${ }^{*}$, John Bosco Mukundi', Aggrey Ochieng' Adimo', \\ John Mwaibanda Wesonga1, Sahar Sodoudi² \\ ${ }^{1}$ Department of Landscape and Environmental Sciences, Jomo Kenyatta University of Agriculture and Technology, Nairobi, Kenya \\ ${ }^{2}$ Institute for Meteorology, Freie University Berlin, Berlin, Germany \\ Email: *shananyango@gmail.com
}

How to cite this paper: Onyango, S. A., Mukundi, J. B., Adimo, A. O., Wesonga, J. M., \& Sodoudi, S. (2021). Variability of InSitu Plant Species Effects on Microclimatic Modification in Urban Open Spaces of Nairobi, Kenya. Current Urban Studies, 9, 126-143.

https://doi.org/10.4236/cus.2021.91008

Received: October 30, 2020

Accepted: March 22, 2021

Published: March 25, 2021

Copyright () 2021 by author(s) and Scientific Research Publishing Inc. This work is licensed under the Creative Commons Attribution International License (CC BY 4.0).

http://creativecommons.org/licenses/by/4.0/

\section{(c) (i) Open Access}

\begin{abstract}
Plant species play a key role in microclimate regulation especially in cities where Urban Heat Island (UHI) effects are mostly felt. This study aimed at determining the impact that different tree species have on microclimatic parameters in urban open spaces of Nairobi and the degree to which they reduce UHI implications and improve Thermal Comfort (TC) of inhabitants. Two sites representing two Local Climate Zones (LCZ) were selected for sampling namely; LCZ B: Central Park (Site 1), and LCZ 4: Taifa road (Site 2). Four mature and isolated in-situ plant species with varied tree architecture were chosen for measurements of climatic variables done at $1.1 \mathrm{~m}$ above the ground, at the trunk base, $5 \mathrm{~m}$ horizontally away from the plant and open in the sun with no trees (control). Leaf area index (LAI) and Physiological Equivalent Temperature (PET) were measured under the trees. In both sites, Terminalia mantaly species with a spreading canopy form provided the best cooling effect with a PET reduction of $9.6^{\circ} \mathrm{C}$ and $9.3^{\circ} \mathrm{C}$ in Site 1 and Site 2, respectively. Tipuana tipu (round canopy form) was the second best with $9.2^{\circ} \mathrm{C}$ and $8.2^{\circ} \mathrm{C}$, followed by Cassia spectabilis (vase canopy form) with $8.5^{\circ} \mathrm{C}$ and $7.6^{\circ} \mathrm{C}$, and lastly Podocarpus falcatus (pyramidal canopy form) with $7.9^{\circ} \mathrm{C}$ and $6.4^{\circ} \mathrm{C}$. Air temperatures in Site 1 (Park) were $2.3^{\circ} \mathrm{C}, 1.3^{\circ} \mathrm{C}$ and $1.0^{\circ} \mathrm{C}$ lower compared to those in Site 2 (Street) at $1 \mathrm{pm}, 6 \mathrm{pm}$ and $8 \mathrm{am}$, respectively. A strong negative correlation ( $\mathrm{S} 1 ; r=-0.96$, S2; $r=-0.8$ ) was obtained between LAI and PET for both sites. This showed that plants with higher canopy densities reduced temperature more, which in turn helps improve human TC.
\end{abstract}

\section{Keywords}

Local Climate Zones (LCZ), Physiological Equivalent Temperature (PET), 
Tree Architecture, Leaf Area Index (LAI), Thermal Comfort (TC), Urban Heat Island (UHI)

\section{Introduction}

Climate in an urban setting differs from that of the surrounding peri-urban and rural zones which brings about UHI (Voogt, 2002; Anjos \& Lopes, 2017; Soltani \& Sharifi, 2017). Urbanization has led to modifications in ground cover types. The vegetative covers and natural soils are substituted by impermeable materials like asphalt and other building materials (Rushton, 2001; Frazer, 2005) that do not allow water infiltration or absorption and change the natural route of storm water (Brattebo \& Booth, 2003). These materials also have low albedo (Voogt, 2002) that store vast amounts of radiation energy and release it later when the sun sets. Architects, Brattebo \& Booth (2003) reported that most urban planners select paving and building supplies based on several specialized necessities such as durability and security together with expenses and normally pay little attention to environmental reasons.

Elevations in ambient temperatures may possibly cause a number of problems with regard to an increased urban thermic discomfort in addition to deterioration of city dwellers' wellbeing (Voogt, 2002; English et al., 2007; Soltani \& Sharifi, 2017). Previous studies have revealed that green spaces in urban sections such as urban gardens and community parks can significantly moderate the ultimate UHI implications (Chiesura, 2004; Feyisa, 2014). Vegetation has a vital function in the prevention of heat build-up through processes like shading of buildings and ground, ventilation and evapotranspiration (English et al., 2007). More contribution of vegetation is towards effective storm water control (Akbari et al., 2001; Brattebo \& Booth, 2003) and enhances air quality in urban domains. Furthermore, vegetation improves out-of-door Thermal Comfort (TC) (Van Hoof et al., 2010; Elnabawi \& Hamza, 2019), offering numerous services of the environment, like carbon storage (Ren, 2011), reducing air pollution and acting as urban biodiversity habitat (Saxe et al., 2001; Georgi \& Zafiriadis, 2006; Bellard, 2012).

In Kenya, the mean annual temperature was estimated to have risen by one degree Celsius from 1960 signifying a mean value of $0.22^{\circ} \mathrm{C}$ increment every ten years (CCN, 2007; Tibaijuka, 2007). A rise of $1.1^{\circ} \mathrm{C}$ to $3.0^{\circ} \mathrm{C}$ temperature through the year 2060 to 2100 is projected; the temperatures may rise with almost four degrees Celsius, producing unevenness in precipitation by about twenty percent (Tibaijuka, 2007). As there are increased shortcomings related to escalated urban temperatures and heat surge, a proposal to develop both adaptation and attenuation techniques was made by Chandler (1962). It entailed integration of green zones in urban domains that showed a potential temperature rollback effects to the inhabitants (Chiesura, 2004; Park et al., 2012; Feyisa, 2014). Nairobi formerly 
had a status as a salubrious residence, it being dubbed as "Green City in the Sun" (CCN, 2007). Conversely, infrastructure development and urban sprawl have vastly contributed to tail-off of forests and most natural sections, like bush lands and mixed rangeland (Tibaijuka, 2007). Thus, vegetation in urban places is increasingly becoming critical to maintaining the quality of a livable environment.

However, there is a dire shortage of information regarding the effectiveness of plants in microclimate control within the diverse urban environments especially in tropical climate settings. Therefore, this study aimed to assess the impact of in-situ plant species on microclimate regulation in the Central Business District (CBD) of Nairobi city. The specific research questions were: how does plant architecture influence the degree of air temperature roll back in the immediate urban settings; when and where is the magnitude of change highest between differing urban surfaces. Information of the study would be useful to urban green managers, landscape designers, arborists and nursery plant suppliers when making decisions with regard to planting design, installation and overall maintenance. Further, the findings contributed to decision-making on urban open space management in relation to plant selection and microclimate regulation in Nairobi.

\section{Materials and Methods}

\subsection{Study Area}

This research site was set out in Nairobi CBD, the capital city of Kenya in East Africa (Figure 1). Nairobi has a dual temperature period; the maximum monthly average recorded in the months of February at approximately $29^{\circ} \mathrm{C}$ in the day and $15^{\circ} \mathrm{C}$ in the nighttime. The minimum temperature is recorded in the months of July at approximately $21^{\circ} \mathrm{C}$ at daytime and $12^{\circ} \mathrm{C}$ at nighttime (Kenya

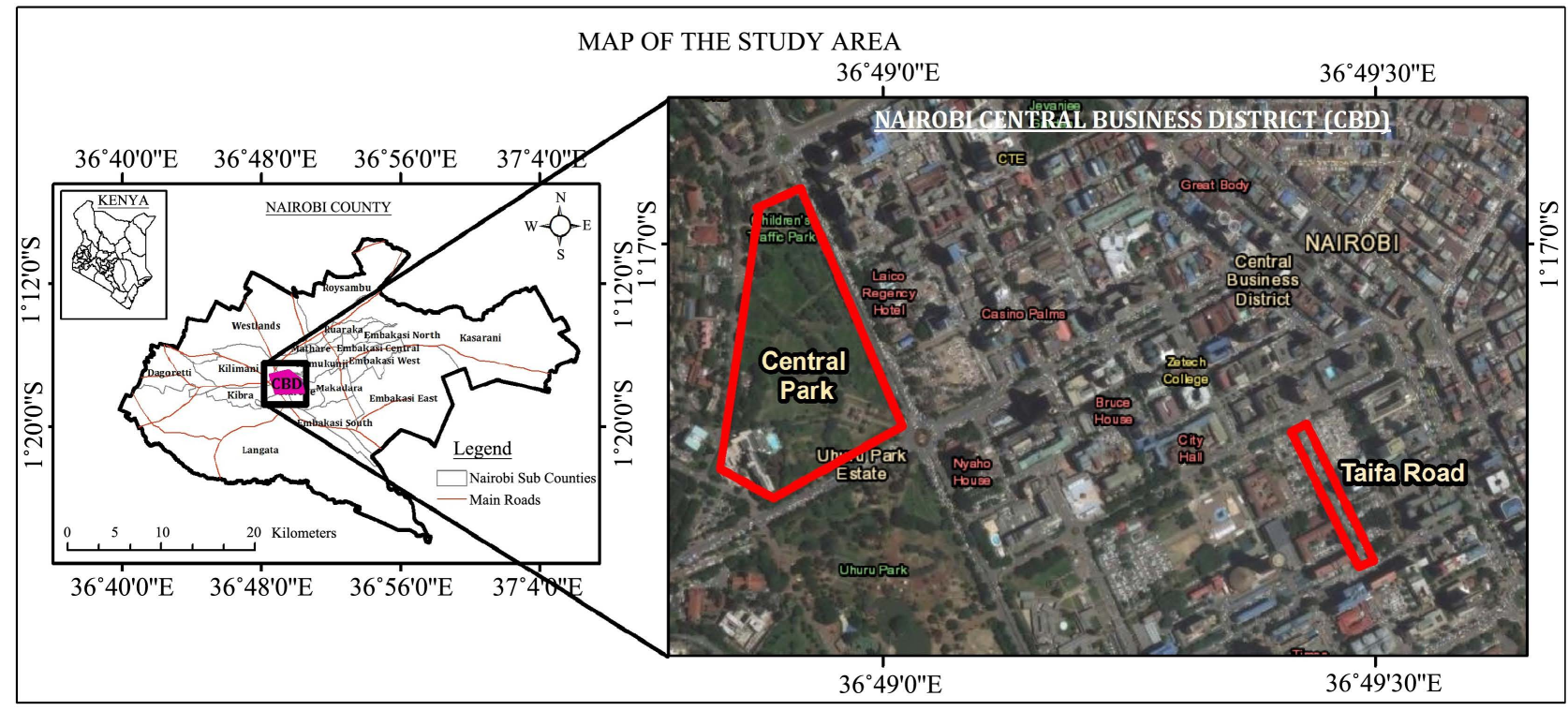

Figure 1. Map showing the geographical location of the study sites within Nairobi City County. 
Meteorological Department (KMD), 2018). The type of downpour in Nairobi is dual-mode; the average monthly precipitation limits vary between a maximum of $195 \mathrm{~mm}$ in April and a minimal of $15 \mathrm{~mm}$ in the months of July throughout the year (KMD, 2018).

Nairobi has a population of approximately $4 \mathrm{~m}$ people, making it the biggest and most populous city in Kenya (Kenya Bureau of Statistics, 2019) and in East Africa. The study is timely in this region as a result of rapid urbanization experienced through the past three decades leading to a significant landscape transformation with an elaborate mix of commercial centers, green open spaces, residential and industrialized sections (Bosco et al., 2011).

\subsection{Sample Sites and Plant Species Selection}

Local Climates Zones (LCZ), a climate-based categorization of both metropolitan and countryside regions developed by Stewart \& Oke (2012) was used to describe the selected study sites. Similar plant species in two different Local Climate Zones (LCZ) within Nairobi Central Business District (CBD) were compared. The two sites representing two local climate zones were namely;

1) LCZ B: Scattered trees; a landscape having grown trees with permeable and low thermal capacity surface, which is also one of the oldest parks in Nairobi, called Central Park (Site 1)

2) LCZ 4: Open high-rise; open organization of tall buildings with scattered trees. The site is characterized with hard and high thermal capacity surfaces such as concrete and glass construction materials. The street is called Taifa road (Site 2).

In each of the two study sites, the most common isolated tree species (in situ plants) that could easily be replicated in both sample sites were identified. Out of this criteria, four plant species were chosen which included; Cassia spectabilis (Cassia), Terminalia mantaly (Umbrella tree), Podocarpus falcatus (Podo/East African yellow wood), and Tipuana tipu (Tipu tree/Rosewood). The types and geometry of the sample in situ trees is shown in Figure 2.

\subsection{Data Collection}

\subsubsection{Plant Canopy Densities and Tree Allometric Properties}

Canopy density was estimated by measuring the Leaf Area Index (LAI) using the LAI-2200C meter. The LAI meter is non-destructive, fast, cost effective, eases on-site evaluation and it can also be used for a variety of plant canopies (Welles \& Norman, 2001; Cater et al., 2009; Fahmy, Sharples, \& Yahiya, 2010; Klingberg et al., 2015). The LAI was recorded at four different points, at the edge of the tree canopy diameter for the above canopy, and also measured at four different points, at the trunk below canopy using the $90^{\circ}$ cap (Cater et al., 2009; Fahmy et al., 2010). The Diameters at Breast Height (DBH) were measured $1.3 \mathrm{~m}$ from the ground using a measuring tape measure. To get the average crown diameters for each tree, two measurements were taken; the widest spread (longer axis) below 


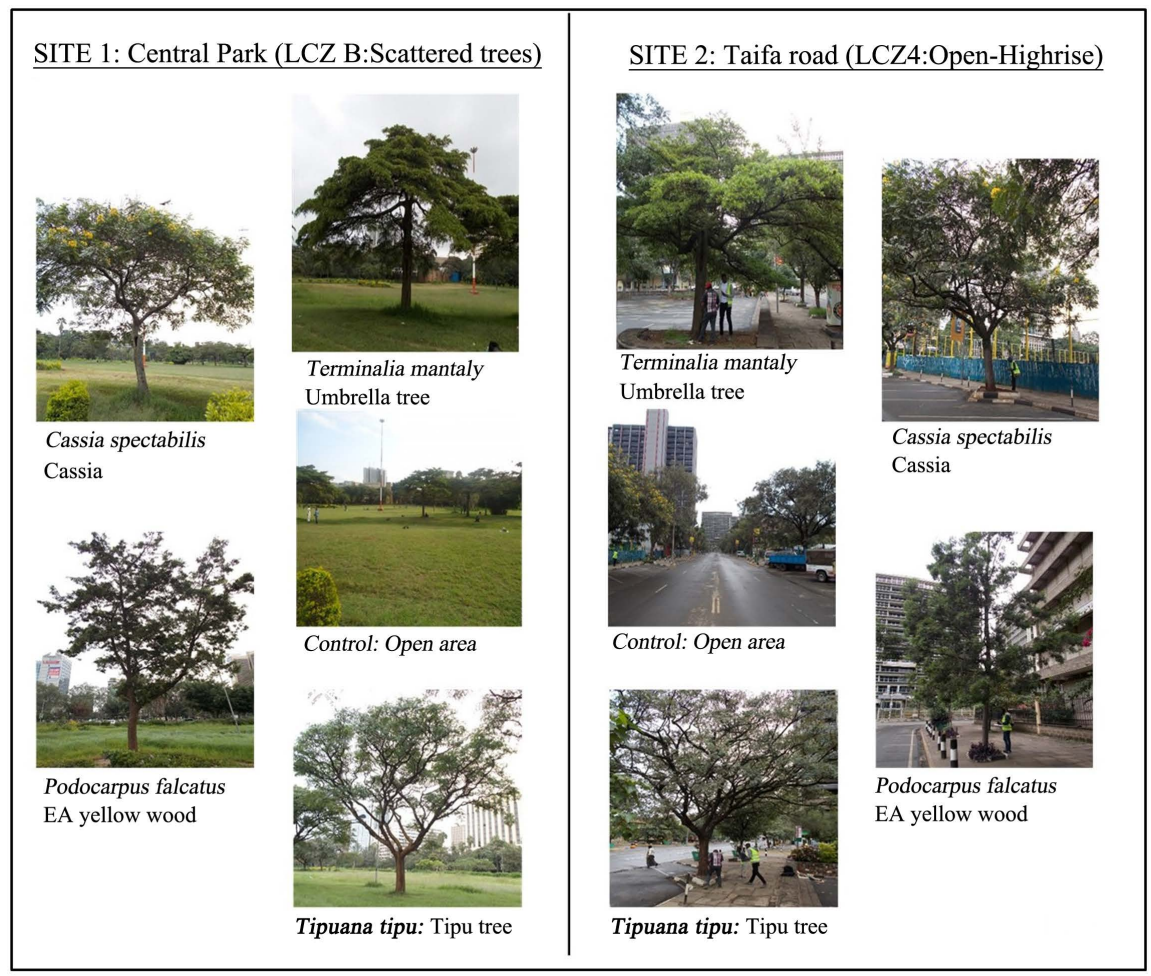

Figure 2. The four different plant species sampled from the two study sites and the control points (open areas with no trees).

the canopy and the widest cross-spread (shorter axis), and the mean $(n=2)$ calculated. To measure the sample tree heights, a Suunto clinometer was used, using the formula:

Tree height $=(($ Distance from tree $) \times \tan (\theta))+$ Height above eye level

\subsubsection{Measurement of Microclimatic Variables}

The microclimatic variables that were measured included; air temperature, the wind speed, relative humidity and surface temperature. Measurement campaign was conducted in the month of May from day 135 up until day 138 of the year 2018. Climatic variables were measured from $0800 \mathrm{hrs}$ to $1800 \mathrm{hrs}$ at interval of 20 minutes for three consecutive days at the same time for the two study sites. They were measured in 3 points, under the tree shades, at $5 \mathrm{~m}$ and away from the shade (in the open with no trees) as a control. Attributes of the study sites and selected plants are shown in Table 1.

Measurements were taken at $1.1 \mathrm{~m}$ above the ground (approximate mean human height) (Rossi et al., 2015). Air temperature and the relative humidity measurements were carried out using PCE-889B digital pyrometers. Surface temperatures were measured using Testo $830-\mathrm{T} 1$ infrared meters and wind speed measurements were taken using Testo 410-2 wind meters. A Geographical Positioning System (GPS) receiver was used to authenticate the geographical locations of the sample sites and the specific trees used for the study (Figure 3). 


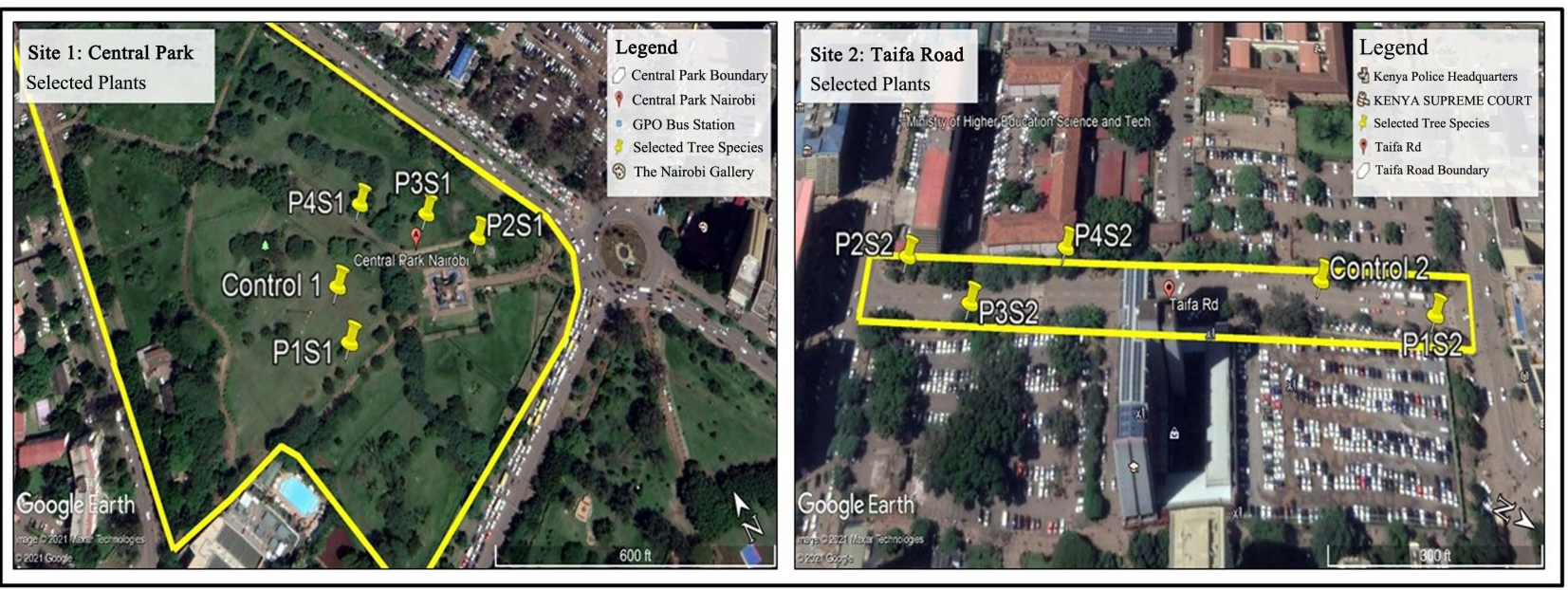

Figure 3. Pinned locations for the sample plants in Central Park (Site 1) and Taifa Road (Site 2) sites. Image Source: Google Earth.

Table 1. Attributes of the study sites; plant (P), site (S) and control (C).

\begin{tabular}{|c|c|c|c|c|}
\hline \multirow{2}{*}{ Code } & \multirow{2}{*}{ Explanation } & \multirow{2}{*}{ Feature } & \multicolumn{2}{|c|}{ GPRS location } \\
\hline & & & Latitude & Longitude \\
\hline $\mathrm{S}_{1}$ & Site 1: (LCZ B; Scattered Trees) & Central Park & $1^{\circ} 17^{\prime} 9.13^{\prime \prime S}$ & $36^{\circ} 48^{\prime} 58.14 " \mathrm{E}$ \\
\hline $\mathrm{S}_{2}$ & Site 2: (LCZ 4; Open High-rise) & Taifa Road & $1^{\circ} 17^{\prime} 14.88^{\prime \prime S}$ & $36^{\circ} 49^{\prime} 27.51 " \mathrm{E}$ \\
\hline $\mathrm{P}_{1} \mathrm{~S}_{1}$ & Plant 1 , Site 1 & Cassia spectabilis & $1^{\circ} 17^{\prime} 10.16^{\prime \prime S}$ & $36^{\circ} 48^{\prime} 55.55^{\prime \prime} \mathrm{E}$ \\
\hline $\mathrm{P}_{2} \mathrm{~S}_{1}$ & Plant 2, Site 1 & Podocarpus falcatus & $1^{\circ} 17^{\prime} 9.87^{\prime \prime S}$ & $36^{\circ} 48^{\prime} 59.25^{\prime \prime} \mathrm{E}$ \\
\hline $\mathrm{P}_{3} \mathrm{~S}_{1}$ & Plant 3, Site 1 & Terminalia mantaly & $1^{\circ} 17^{\prime} 8.80^{\prime \prime S}$ & $36^{\circ} 48^{\prime} 58.45^{\prime \prime} \mathrm{E}$ \\
\hline $\mathrm{P}_{4} \mathrm{~S}_{1}$ & Plant 4 , Site 1 & Tipuana tipu & $1^{\circ} 17^{\prime} 7.81^{\prime \prime S}$ & $36^{\circ} 48^{\prime} 57.14^{\prime \prime} \mathrm{E}$ \\
\hline $\mathrm{C}_{1}$ & Control area for Site 1 & Site 1 & $1^{\circ} 17^{\prime} 9.05^{\prime \prime S}$ & $36^{\circ} 48^{\prime} 55.84^{\prime \prime} \mathrm{E}$ \\
\hline $\mathrm{P}_{1} \mathrm{~S}_{2}$ & Plant 1 , Site 2 & Cassia spectabilis & $1^{\circ} 17^{\prime} 10.98^{\prime \prime S}$ & $36^{\circ} 49^{\prime} 25.97^{\prime \prime} \mathrm{E}$ \\
\hline $\mathrm{P}_{2} \mathrm{~S}_{2}$ & Plant 2, Site 2 & Podocarpus falcatus & $1^{\circ} 17^{\prime} 18.69^{\prime \prime S}$ & $36^{\circ} 49^{\prime} 29.23^{\prime \prime} \mathrm{E}$ \\
\hline $\mathrm{P}_{3} \mathrm{~S}_{2}$ & Plant 3, Site 2 & Terminalia mantaly & $1^{\circ} 17^{\prime} 17.44^{\prime \prime S}$ & $36^{\circ} 49^{\prime} 29.27^{\prime \prime} \mathrm{E}$ \\
\hline $\mathrm{P}_{4} \mathrm{~S}_{2}$ & Plant 4, Site 2 & Tipuana tipu & $1^{\circ} 17^{\prime} 16.52^{\prime \prime S}$ & $36^{\circ} 49^{\prime} 27.91^{\prime \prime} \mathrm{E}$ \\
\hline $\mathrm{C}_{2}$ & Control area for Site 2 & Site 2 & $1^{\circ} 17^{\prime} 12.72 " S$ & $36^{\circ} 49^{\prime} 26.38^{\prime \prime} \mathrm{E}$ \\
\hline
\end{tabular}

\subsubsection{Human Thermal Comfort}

To ascertain the temperature reduction impact of the trees in relation to human thermal comfort, PET was used as the thermal index. Fish-eye photographs (FEP) were taken under the trees and away from the tree shades (control) at 1 $\mathrm{pm}$, as at this time the maximum heat effect of the sun is mostly felt (Chen et al., 2012; Middel et al., 2018). The FEP and the climate data were used to compute the Sky View Factor (SVF) and PET by the use of Rayman software (Matzarakis et al., 2009; Deb \& Alur, 2010).

SVF values range from 0 to 1 (Chapman \& Thrones, 2004; Middel et al., 2018) $(\mathrm{SVF}=0$; the sky is fully covered with an obstacle). PET and SVF were then used to determine the thermal reduction effect of the trees compared to their surrounding and determine the thermal comfort range under and away from the trees as described by (Matzarakis \& Mayer, 1997; Matzarakis \& Amelung, 2008) (Table 2). 
Table 2. The comfort index of PET formulated for specific elemental thermal conditions.

\begin{tabular}{ccc}
\hline PET $\left({ }^{\circ} \mathrm{C}\right)$ & Thermal Impression & Degree of physiological stress \\
\hline$<4.0$ & Very cold & Extreme cold stress \\
$4.1-8.0$ & Cold & Strong cold stress \\
$8.1-13.0$ & Cool & Moderate cold stress \\
$13.1-18.0$ & Slightly cool & Slightly cold stress \\
$18.1-23.0$ & Neutral (comfortable) & No thermal stress \\
$23.1-29.0$ & Slightly warm & Slightly heat stress \\
$29.1-35.0$ & Warm & Moderate heat stress \\
$35.1-41.0$ & Hot & Strong heat stress \\
$41>$ & Very hot & Extreme heat stress \\
\hline
\end{tabular}

\subsection{Data Analysis}

The means of the collected microclimate data $(n=3)$ were calculated and the results used to show the continuous distribution from 8 am to $6 \mathrm{pm}$ (10 hours) for both sites. Data for three specific hours; $8 \mathrm{am}, 1 \mathrm{pm}$ and $6 \mathrm{pm}$ were extracted from the entire 20-minute interval data set and was used for analysis. This is because, at 8 am the air is still chilled, at $1 \mathrm{pm}$ the air is quite heated up by the scorching sun and at $6 \mathrm{pm}$ the sun is down and the heat islands knock-on-effect is felt. The data in this study was assumed not to follow a normal distribution, as the population was not homogenous. Statistical Package for Social Sciences (SPSS) software was used to statistically evaluate the measured microclimatic parameters.

To reduce possibilities of skewed data distribution, Kruskal-Wallis non-parametric analysis of variance (ANOVA) was used for statistical evaluation of the significant difference among the means of microclimate variables measured. Mann-Whitney's U Test was then used to investigate the significant distinction between the two independent study sample sites (inter-sites). Whenever $p$ was $<$ 0.05 the mean difference was deemed as a statistical significance. Values of SVF and PET obtained from the Rayman model were used to assess the human thermal comfort under the trees along with the control areas (Figure 4). Simple correlation analysis was performed between LAI and PET. Results were presented in graphs and tables.

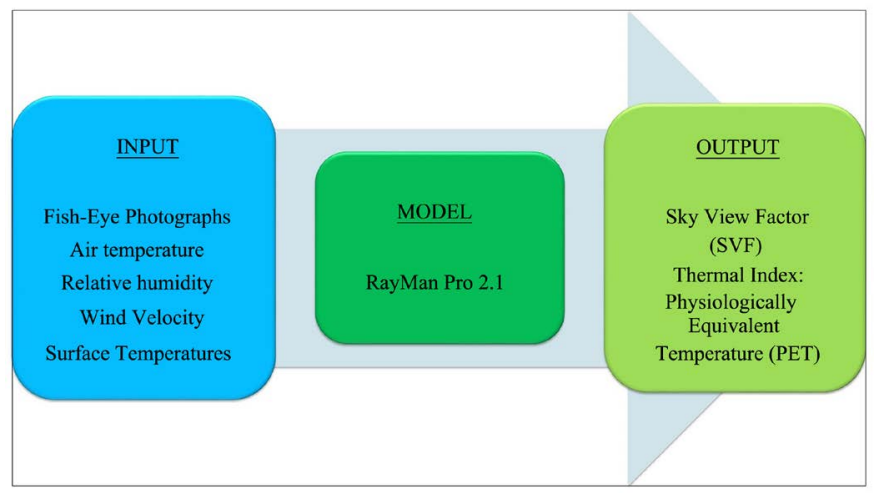

Figure 4. Overview of PET analysis process. 


\section{Results and Discussion}

\subsection{Plant Canopy Density Determination and the Tree Allometric Properties}

The measured LAI values were used to determine the sample plants' canopy densities. Terminalia mantaly (P3) had the highest density in both two sites with the value of 4.03 and 4.08 in Site 1 (CP) and Site 2 (TR), respectively. Tipuana tipu (P4) was the second highest with 3.58 and 3.85, followed by Cassia spectabilis (P1) with 3.25 and 3.43, and finally Podocarpus falcatus (P2) with 3.02 and 3.21. The plant species in Site 2 (TR) had slightly higher densities than those in Site 1 (CP) with a difference of $0.18,0.20,0.04$ and 0.27 for P1, P2, P3 and P4, respectively (Table 3 ). The tree allometric properties that were measured were the Diameter at Breast Height (DBH), tree height and the crown diameter.

Table 3. Selected plants' allometric properties; Site 1: CP-Central Park, Site 2: TR-Taifa Road.

\begin{tabular}{lcccccccc}
\hline \multirow{2}{*}{ Plant Species } & \multicolumn{2}{c}{ LAI } & \multicolumn{2}{c}{ DBH (m) } & \multicolumn{2}{c}{ Crown Diameter (m) } & \multicolumn{2}{c}{ Tree Height (m) } \\
\cline { 2 - 8 } & C P & T R & C P & T R & C P & T R & C P & T R \\
\hline P1: Cassia spectabilis & 3.25 & 3.43 & 0.83 & 0.80 & 8.00 & 8.20 & 7.90 & 7.60 \\
P2: Podocarpus falcutus & 3.02 & 3.21 & 0.80 & 0.76 & 7.60 & 7.00 & 8.90 & 8.50 \\
P3: Terminalia mantally & 4.03 & 4.08 & 0.95 & 0.93 & 10.80 & 10.40 & 8.50 & 8.30 \\
P4: Tipuana tipu & 3.58 & 3.85 & 0.89 & 0.87 & 10.10 & 10.00 & 8.20 & 7.70 \\
\hline
\end{tabular}

\subsection{Mean Microclimate Distribution at the Trunk and at $5 \mathrm{~m}$}

The results of the calculated mean microclimate parameters were presented in graphs to show the continuous distribution for the ten hours measurement period. This was done for both Site 1 (Figure 5) and Site 2 (Figure 6), at the trunk and $5 \mathrm{~m}$ away from the trunk.

\subsection{Inter-Site/Inter-Species Effects on Microclimatic Parameters}

\subsubsection{Air Temperature (AT)}

Mean ambient temperatures $(n=3)$ in the park (Site 1$)$ were $2.1 \%\left(1.0^{\circ} \mathrm{C}\right), 3.3 \%$ $\left(2.3^{\circ} \mathrm{C}\right)$ and $2.6 \%\left(1.3^{\circ} \mathrm{C}\right)$ lower than the AT along the street (Site 2$)$ at $8 \mathrm{am}, 1$ $\mathrm{pm}$ and $6 \mathrm{pm}$, respectively. The highest temperatures were recorded at $1 \mathrm{pm}$, followed by $6 \mathrm{pm}$ and the lowest at 8 am for all the plant species, at the trunk, 5 $\mathrm{m}$ away and at the control points (Table 4). At the trunk, AT was lower compared to the AT $5 \mathrm{~m}$ away from the trunk and the highest recorded being at the control point with no trees. In both sites, the lowest AT was recorded under Terminalia mantaly (P3) with $20.4^{\circ} \mathrm{C}$ and $20.7^{\circ} \mathrm{C}$, respectively, followed by $T i$ puana tipu (P4) with $20.7^{\circ} \mathrm{C}$ and $20.8^{\circ} \mathrm{C}$. Thirdly Cassia spectabilis (P1) followed with $20.9^{\circ} \mathrm{C}$ and $21.0^{\circ} \mathrm{C}$, Podocarpus falcatus (P2) followed with $21.2^{\circ} \mathrm{C}$ and $21.3^{\circ} \mathrm{C}$ and finally at the control with $23.3^{\circ} \mathrm{C}$ and $23.5^{\circ} \mathrm{C}$ correspondingly (Table 4). The highest AT were recorded at the control at $1 \mathrm{pm}-5 \mathrm{~m}$ away from the 


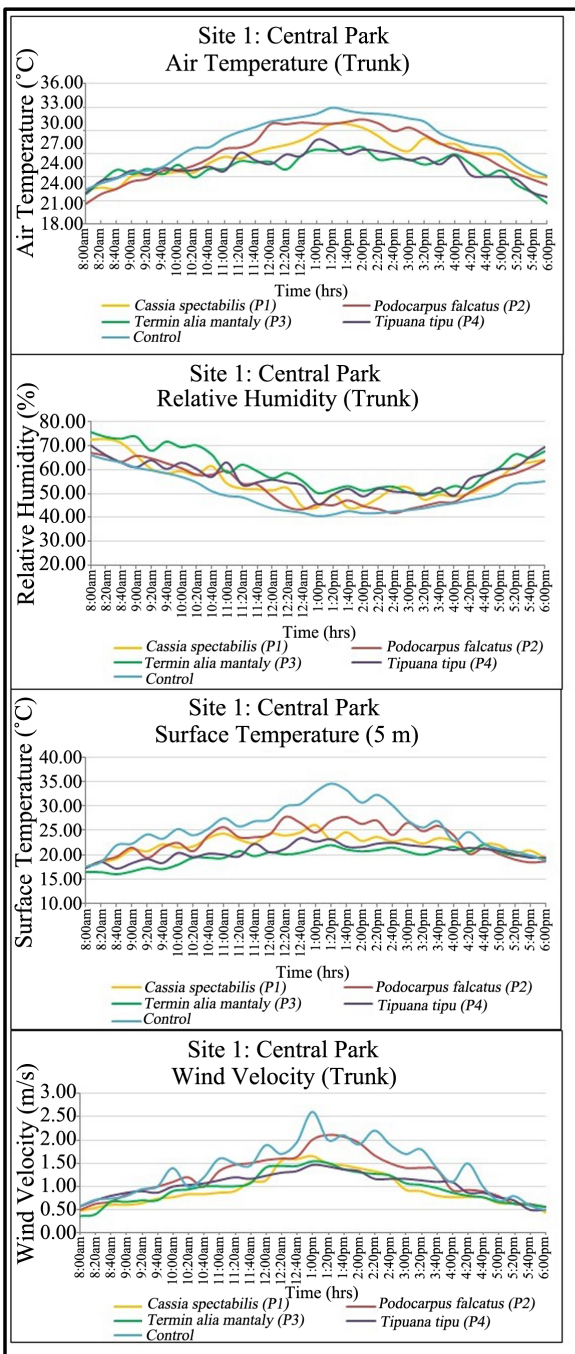

(a)

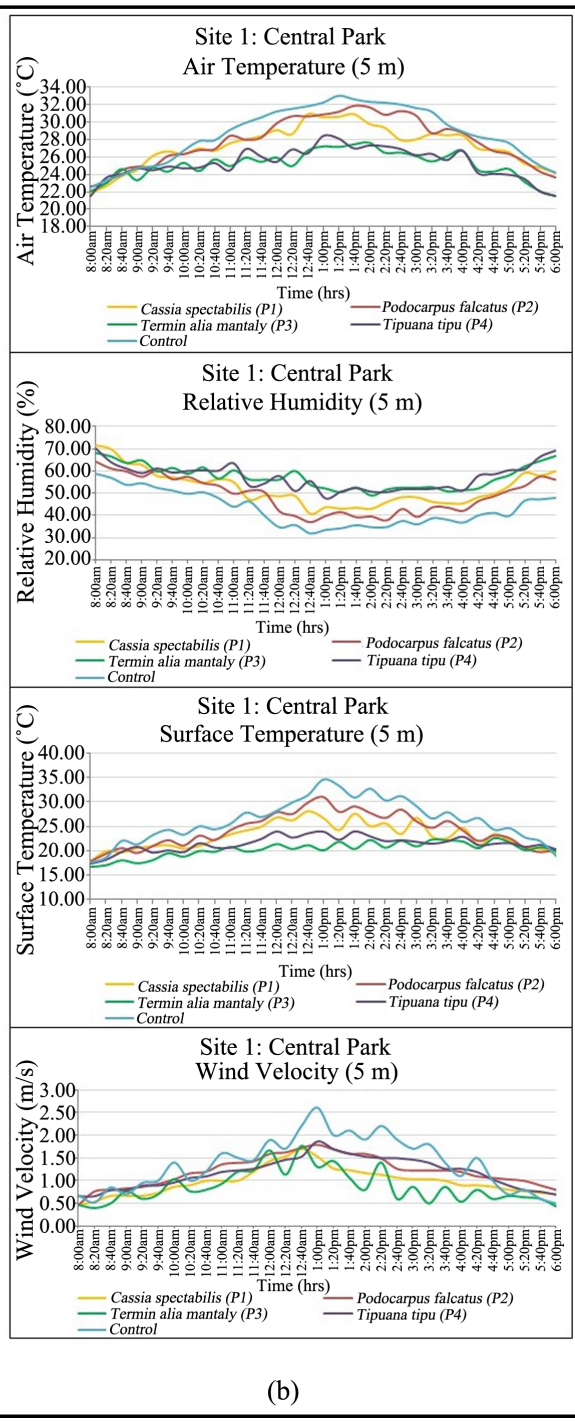

(b)

Figure 5. Site 1 (Central Park) mean microclimate distribution at the trunk and at $5 \mathrm{~m}$.

trunk with $33.9^{\circ} \mathrm{C}$ and $36.2^{\circ} \mathrm{C}$ for both Site 1 and Site 2, respectively. A significant variation in $\mathrm{AT}$ was achieved between the plant species, the time and levels of measurement for each independent site $(p<0.05)$ and no significant differences between both sites at $8 \mathrm{am}(p=0.880)$ (Table 4$)$.

\subsubsection{Relative Humidity (RH)}

The mean RH $(n=3)$ was $1.4 \%, 8.2 \%$ and $9.3 \%$ higher in Site 1 compared to Site 2 at $8 \mathrm{am}, 6 \mathrm{pm}$ and $1 \mathrm{pm}$ respectively. It showed a general trend with highest values recorded at the trunk level, followed by the $5 \mathrm{~m}$ and lastly at the control (Table 4). A significant change in RH was noted between the plant species, the timing and levels of measurement for both independent sites $(p<0.05)$. In the two sites, the highest RH was recorded under P3 (Terminalia mantaly) with $74.6 \%$ and $71.7 \%$ in Site 1 and 2, respectively. Second was P4 with $71.3 \%$ and $68.2 \%$, followed by P1 with $70.1 \%$ and $67.6 \%$, and lastly P2 with $64 \%$ and $63.4 \%$. 


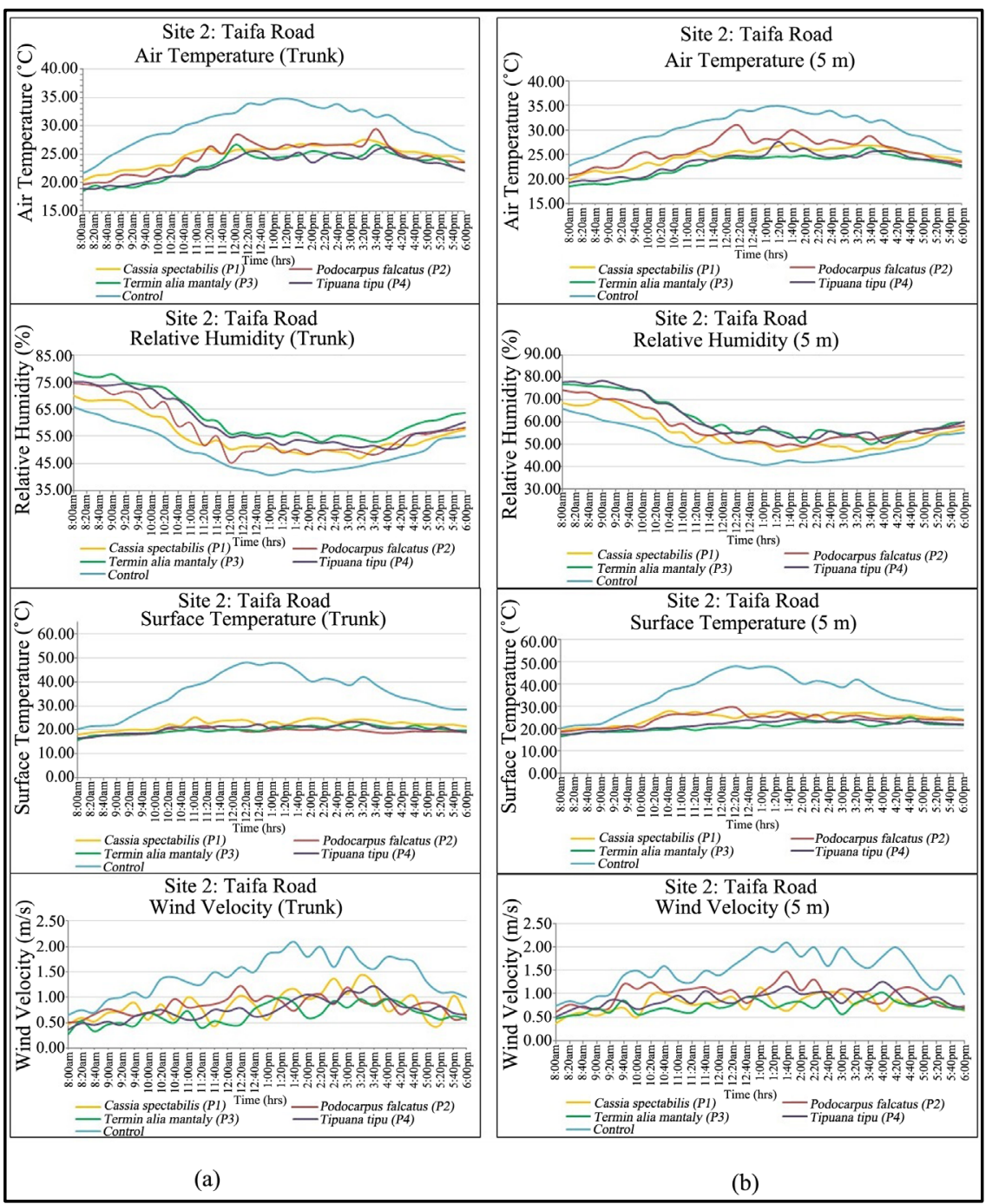

Figure 6. Site 2 (Taifa Road) mean microclimate distribution at the trunk and at $5 \mathrm{~m}$.

All of these were recorded at $8 \mathrm{am}$. Control had the lowest RH with $38.2 \%$ and $30 \%$ both recorded at $1 \mathrm{pm}-5 \mathrm{~m}$ in the respective sites (Table 4 ).

\subsubsection{Surface Temperature (ST)}

The mean ST $(n=3)$ in Site 2 were $8.2 \%\left(3.5^{\circ} \mathrm{C}\right), 9.1 \%\left(6.4^{\circ} \mathrm{C}\right)$ and $10.6 \%\left(5^{\circ} \mathrm{C}\right)$ warmer compared to Site 1 at $8 \mathrm{am}, 1 \mathrm{pm}$ and $6 \mathrm{pm}$ respectively. A general trend of cooler surfaces was shown at $8 \mathrm{am}$, slightly warmer at $6 \mathrm{pm}$ and warmest at 1 pm (Table 4). A significant distinction in ST was achieved between the plant species, the time and levels of measurement for both independent sites $(p<$ 0.05). The lowest ST were measured under $\mathrm{P} 3$ with $16.5^{\circ} \mathrm{C}$ and $17.5^{\circ} \mathrm{C}$ in Site 1 and Site 2, correspondingly (Table 4). This was followed closely by $\mathrm{P} 4$ with $16.9^{\circ} \mathrm{C}$ and $18.4^{\circ} \mathrm{C}$, thirdly by $\mathrm{P} 1$ with $17.1^{\circ} \mathrm{C}$ and $19.2^{\circ} \mathrm{C}$ and lastly $\mathrm{P} 2$ with $17.5^{\circ} \mathrm{C}$ and $19.5^{\circ} \mathrm{C}$. All of the lowest temperatures were recorded at $8 \mathrm{am}$. The highest ST recorded were at the control with $31.8^{\circ} \mathrm{C}$ and $43.2^{\circ} \mathrm{C}$ measured $5 \mathrm{~m}$ away at $1 \mathrm{pm}$ both sites (Table 4). 
Table 4. Mean microclimate measurements under the plant species within the two study sample sites.

\begin{tabular}{|c|c|c|c|c|c|c|c|c|c|c|c|c|c|}
\hline \multirow{3}{*}{$\begin{array}{l}\text { Climatic } \\
\text { variables }\end{array}$} & \multirow{3}{*}{ Plant } & \multicolumn{6}{|c|}{ SITE 1 (CENTRAL PARK) } & \multicolumn{6}{|c|}{ SITE 2 (TAIFA ROAD) } \\
\hline & & \multicolumn{2}{|c|}{$8 \mathrm{am}$} & \multicolumn{2}{|c|}{$1 \mathrm{pm}$} & \multicolumn{2}{|c|}{$6 \mathrm{pm}$} & \multicolumn{2}{|c|}{$8 \mathrm{am}$} & \multicolumn{2}{|c|}{$1 \mathrm{pm}$} & \multicolumn{2}{|c|}{$6 \mathrm{pm}$} \\
\hline & & Trunk & $5 \mathrm{~m}$ & Trunk & $5 \mathrm{~m}$ & Trunk & $5 \mathrm{~m}$ & Trunk & $5 \mathrm{~m}$ & Trunk & $5 \mathrm{~m}$ & Trunk & $5 \mathrm{~m}$ \\
\hline \multirow{8}{*}{$\begin{array}{c}\text { Air } \\
\text { Temp. } \\
\left({ }^{\circ} \mathrm{C}\right)\end{array}$} & P1 & 20.9 & 22.8 & 25.9 & 26.2 & 23.0 & 23.1 & 21.0 & 21.4 & 31.2 & 31.2 & 23.6 & 23.8 \\
\hline & P2 & 21.2 & 22.6 & 25.9 & 25.9 & 23.4 & 23.7 & 21.3 & 21.4 & 29.9 & 33.4 & 23.6 & 23.6 \\
\hline & P3 & 20.5 & 20.9 & 24.3 & 24.3 & 20.9 & 21.5 & 20.8 & 20.8 & 27.5 & 27.2 & 22.0 & 22.4 \\
\hline & $\mathrm{P} 4$ & 20.7 & 21.5 & 24.1 & 23.5 & 21.4 & 21.5 & 20.8 & 21.1 & 28.8 & 28.9 & 22.1 & 22.7 \\
\hline & Control & 23.3 & 24.5 & 33.3 & 33.9 & 24.0 & 24.2 & 23.5 & 25.5 & 35.4 & 36.2 & 25.2 & 25.5 \\
\hline & \multicolumn{13}{|c|}{$C P: K . W 8$ am $(p=0.003) K . W 1 \mathrm{pm}(p=0.012) K . W 6 \mathrm{pm}(p=0.02) K . W$ Overall $(p=0.03)$} \\
\hline & \multicolumn{13}{|c|}{ TR: K.W 8 am $(p=0.007) K . W 1 \mathrm{pm}(p=0.032) K . W 6 \mathrm{pm}(p=0.002) K . W$ Overall $(p=0.007)$} \\
\hline & \multicolumn{13}{|c|}{${ }^{*} M . W 8$ am $(p=0.880) M . W 1 \mathrm{pm}(p=0.008) M . W 6 \mathrm{pm}(p=0.025) M . W$ Overall $(p=0.035)$} \\
\hline \multirow{8}{*}{$\begin{array}{c}\text { Relative } \\
\text { Humidity } \\
\quad(\%)\end{array}$} & P1 & 70.2 & 69.5 & 50.9 & 48.6 & 63.7 & 59.8 & 67.2 & 67.6 & 44.8 & 43.7 & 57.3 & 57.0 \\
\hline & P2 & 63.9 & 64.4 & 48.4 & 47.3 & 59.8 & 57.6 & 63.4 & 62.9 & 41.2 & 39.0 & 56.1 & 55.2 \\
\hline & P3 & 74.6 & 73.6 & 57.7 & 57.4 & 68.7 & 67.1 & 71.7 & 70.0 & 53.2 & 52.1 & 61.4 & 59.8 \\
\hline & P4 & 71.3 & 70.0 & 55.6 & 55.5 & 67.9 & 66.9 & 68.2 & 67.8 & 48.8 & 47.6 & 60.2 & 60.0 \\
\hline & Control & 64.9 & 64.3 & 38.7 & 38.2 & 65.4 & 64.4 & 63.9 & 62.9 & 32.2 & 30.0 & 55.4 & 55.1 \\
\hline & \multicolumn{13}{|c|}{$C P: K . W 8$ am $(p=0.006) K . W 1 p m(p=0.002) K . W 6 p m(p=0.02) K . W$ Overall $(p=0.04)$} \\
\hline & \multicolumn{13}{|c|}{ TR: K.W 8 am $(p=0.003) K . W 1 \mathrm{pm}(p=0.004) K . W 6 \mathrm{pm}(p=0.007) K . W$ Overall $(p=0.007)$} \\
\hline & \multicolumn{13}{|c|}{$M . W 8$ am $(p=0.012) M . W 1 \mathrm{pm}(p=0.009) M . W 6 \mathrm{pm}(p=0.004) M . W$ Overall $(p=0.049)$} \\
\hline \multirow{8}{*}{$\begin{array}{l}\text { Surface } \\
\text { Temp. } \\
\left({ }^{\circ} \mathrm{C}\right)\end{array}$} & $\mathrm{P} 1$ & 17.1 & 17.4 & 23.2 & 25.7 & 19.2 & 19.4 & 19.2 & 19.2 & 33.5 & 34.5 & 21.4 & 23.1 \\
\hline & $\mathrm{P} 2$ & 17.5 & 18.5 & 26.2 & 28.0 & 19.6 & 19.9 & 19.5 & 19.8 & 35.7 & 36.9 & 23.9 & 25.0 \\
\hline & P3 & 16.5 & 17.1 & 21.1 & 22.2 & 18.2 & 18.9 & 17.5 & 17.8 & 28.2 & 29.0 & 19.6 & 21.9 \\
\hline & P4 & 16.9 & 17.5 & 22.6 & 24.0 & 19.2 & 19.4 & 18.4 & 18.6 & 30.2 & 31.2 & 20.8 & 22.0 \\
\hline & Control & 19.6 & 19.7 & 31.6 & 31.8 & 20.8 & 21.0 & 22.2 & 23.2 & 37.4 & 38.2 & 28.4 & 29.4 \\
\hline & \multicolumn{13}{|c|}{$C P: K . W 8$ am $(p=0.01) K . W 1 \mathrm{pm}(p=0.02) K . W 6 p m(p=0.03) K . W$ Overall $(p=0.01)$} \\
\hline & \multicolumn{13}{|c|}{ TR: K.W $8 \mathrm{am}(p=0.020) K . W 1 \mathrm{pm}(p=0.008) K . W 6 \mathrm{pm}(p=0.029) K . W$ Overall $(p=0.026)$} \\
\hline & \multicolumn{13}{|c|}{$M . W 8$ am $(p=0.015) M . W 1 \mathrm{pm}(p=0.001) M . W 6 \mathrm{pm}(p=0.001) M . W$ Overall $(p=0.005)$} \\
\hline \multirow{8}{*}{$\begin{array}{c}\text { Wind } \\
\text { Velocity } \\
(\mathrm{m} / \mathrm{s})\end{array}$} & P1 & 0.5 & 0.6 & 0.5 & 0.7 & 0.6 & 0.7 & 0.6 & 0.6 & 0.8 & 0.9 & 0.8 & 0.9 \\
\hline & $\mathrm{P} 2$ & 0.6 & 0.7 & 0.8 & 0.9 & 0.5 & 0.9 & 0.7 & 0.6 & 1.2 & 1.3 & 1.0 & 1.1 \\
\hline & P3 & 0.7 & 0.6 & 0.7 & 0.8 & 0.6 & 0.6 & 0.6 & 0.5 & 0.9 & 0.8 & 0.6 & 0.8 \\
\hline & P4 & 0.5 & 0.8 & 0.6 & 0.8 & 0.5 & 0.7 & 0.6 & 0.5 & 0.9 & 1.1 & 0.7 & 0.8 \\
\hline & Control & 0.8 & 0.8 & 1.2 & 1.2 & 0.8 & 0.9 & 0.9 & 1.0 & 1.4 & 1.8 & 0.9 & 0.9 \\
\hline & \multicolumn{13}{|c|}{$C P: K . W 8$ am $(p=0.03) K . W 1 \mathrm{pm}(p=0.023) K . W 6 \mathrm{pm}(p=0.024) K . W$ Overall $(p=0.02)$} \\
\hline & \multicolumn{13}{|c|}{ TR: $K . W 8 \mathrm{am}(p=0.028) K . W 1 \mathrm{pm}(p=0.042){ }^{\star} K . W 6 \mathrm{pm}(p=0.143) K . W$ Overall $(p=0.001)$} \\
\hline & & & $8 \mathrm{am}$ & $=0.820$ & 1. $W 1$ & $n(p=0.6$ & D) $M . V$ & $\operatorname{pm}(p=$ & 011) 1 & W Overa & $p=0$. & & \\
\hline
\end{tabular}

K.W: Kruskal Wallis Test, M.W: Mann Whitney U Test, CP: Central Park, TR: Taifa Road. 


\subsubsection{Wind Velocity (WV)}

The mean WV $(n=3)$ in Site 2 was $8.7 \%(0.2 \mathrm{~m} / \mathrm{s}), 11 \%(0.3 \mathrm{~m} / \mathrm{s})$ and $4.9 \%(0.1$ $\mathrm{m} / \mathrm{s}$ ) higher compared to Site 1 at $8 \mathrm{am}, 1 \mathrm{pm}$ and $6 \mathrm{pm}$, respectively (Table 4). It showed no general trend in either site but the highest wind velocity trends were recorded in the afternoon and slightly towards the evening at $6 \mathrm{pm}$ in both sites. A significant change in WV was obtained between the plant species, time and levels of measurement for both independent sites at 8 am and $1 \mathrm{pm}$ ( $p<$ $0.05)$ with no significant differences at $6 \mathrm{pm}(p=0.143)$. Significant change between the two sites was noted at $1 \mathrm{pm}$ and $6 \mathrm{pm}(p<0.05)$ with no significant differences at $8 \mathrm{am}(p=0.820)$ (Table 4). In Site 1 , the lowest WV was $0.5 \mathrm{~m} / \mathrm{s}$ recorded under P1-8 am and P4-6 pm both at the trunk. The highest WV was $1.2 \mathrm{~m} / \mathrm{s}$ recorded at the control, both at the tree trunk and $5 \mathrm{~m}$ away at $1 \mathrm{pm}$. In Site 2, the lowest WV was recorded under P3 and P4 both with $0.53 \mathrm{~m} / \mathrm{s}$ at $8 \mathrm{am}$. $\mathrm{P} 1$ followed with $0.63 \mathrm{~m} / \mathrm{s}$ and P2 with $0.65 \mathrm{~m} / \mathrm{s}$. The highest WV was $1.8 \mathrm{~m} / \mathrm{s}$ recorded at $1 \mathrm{pm}, 5 \mathrm{~m}$ away from the trunk in Site 2 (Table 4).

\subsection{Human Thermal Comfort (TC) Evaluation}

Plants in Site 2 had relatively higher values for both SVF and PET compared to plants in Site 1 (Figure 7). The PET range for Site 1, for all the species was between $22^{\circ} \mathrm{C}$ and $23.7^{\circ} \mathrm{C}$ (Figure 7) which implies a neutral to slightly warm thermal perception for the users under the trees (Table 2). In Site 2, the PET range was between $25.5^{\circ} \mathrm{C}$ and $28^{\circ} \mathrm{C}$ (Figure 7) implying a slight heat stress for the users under the trees (Table 2). This shows that Site 2 was warmer than Site 1 by a range of $3.5^{\circ} \mathrm{C}$ to $4.3^{\circ} \mathrm{C}$. The sections with no trees (control) in both sites exhibited warm thermal perception with that of Site 2 being $3.2^{\circ} \mathrm{C}$ warmer than Site 1 (Figure 7). Users of these spaces with no trees are likely to suffer moderate heat stress (Table 2).

P3 had the lowest PET in both sites with $22^{\circ} \mathrm{C}$ and $25.5^{\circ} \mathrm{C}$, exhibiting a percentage temperature reduction of $18 \%\left(9.6^{\circ} \mathrm{C}\right)$ and $15 \%\left(9.3^{\circ} \mathrm{C}\right)$ in Site 1 and 2 respectively (Figure 7). People under this tree experience neutral thermal perception and are comfortable with no thermal stress in Site 1 while being under the same tree in Site 2, they experience a slight heat stress (Table 2).

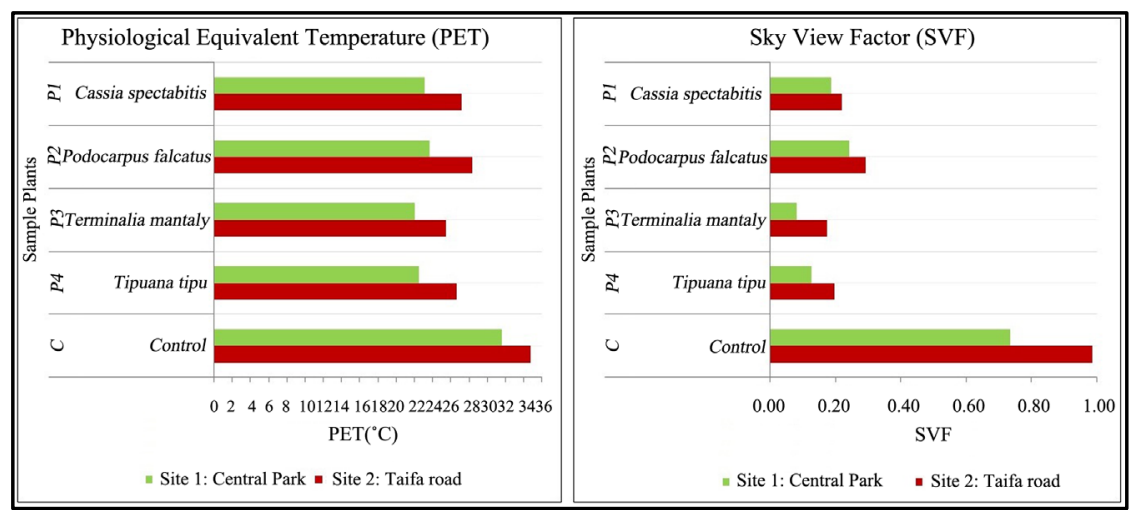

Figure 7. PET and SVF distribution for both sample sites. 
$\mathrm{P} 4$ had the second lowest with $22.4^{\circ} \mathrm{C}$ and $26.6^{\circ} \mathrm{C}$, a temperature reduction of $17 \%\left(9.2^{\circ} \mathrm{C}\right)$ and $13 \%\left(8.2^{\circ} \mathrm{C}\right)$ (Figure 7$)$. The same thermal perception as that $\mathrm{P} 3$ is experienced by the users under this plant but with slightly higher temperature differences of $0.4^{\circ} \mathrm{C}$ and $1.1^{\circ} \mathrm{C}$ than those under $\mathrm{P} 3$ in both sites respectively. P1 had the third-lowest PET with $23.1^{\circ} \mathrm{C}$ and $27.2^{\circ} \mathrm{C}$, a reduction of $16 \%$ $\left(8.5^{\circ} \mathrm{C}\right)$ and $12 \%\left(7.6^{\circ} \mathrm{C}\right)$ respectively (Figure 7$)$. The persons under this tree experience a slight heat stress in both sites (Table 2).

P2 had the highest PET among all the four species with $23.7^{\circ} \mathrm{C}$ and $28.4^{\circ} \mathrm{C}$, a reduction of $14 \%\left(7.9^{\circ} \mathrm{C}\right)$ and $10 \%\left(6.4^{\circ} \mathrm{C}\right)$ in both sites. People are likely to experience a slight heat stress under this tree in both sites similar to P1 but with temperature differences of $0.6^{\circ} \mathrm{C}$ and $1.2^{\circ} \mathrm{C}$ higher than those under $\mathrm{P} 1$ in both sites (Figure 7). A strong negative correlation between the LAI and PET was obtained from both sites ( $\mathrm{S} 1 ; r=-0.96, \mathrm{~S} 2 ; r=-0.8)$. This implying that an increase in LAI reduces PET and a decrease in LAI would most likely cause a higher PET under the plants' shade.

\section{Discussion}

AT is much higher in urban regions resulting from human activities which include construction, burning of fossil fuels and use of motor vehicles (Akbari et al., 2001; Atkinson et al., 2007; Morris, 2010) that highly contribute to production of anthropogenic heat causing the buildup of UHI (Voogt, 2002). UHI alters the human thermal comfort and poses adverse environmental and health implications to the urban residents (Voogt, 2002; Santamouris et al., 2017). In this study, the plant species in both the park and the street were able to regulate microclimate regardless of their external environments. Notably, the temperatures in the park were lower compared to the temperatures at the street and this cut across all the species. The park was able to reduce the AT by $3.3 \%\left(2.3^{\circ} \mathrm{C}\right)$ than the street at $1 \mathrm{pm}$ when it is mostly hot and by $2.6 \%\left(1.3^{\circ} \mathrm{C}\right)$ in the evening at 6 pm when the effect of UHI is felt.

The park was also able to increase the RH by $8.2 \%$ and $9.3 \%$ than the street both at $1 \mathrm{pm}$ and at $6 \mathrm{pm}$, respectively. This shows that improving tree cover within urban open spaces will help reduce AT and increase $\mathrm{RH}$ making the outof-door spaces comfortable for the urban dwellers (Narita et al., 2008; Loughner et al., 2012; Feyisa, 2014). When urban greenery is lost, the lesser its surface area will be, the lesser the rate of evapotranspiration (Leuzinger et al., 2010; Lin et al., 2017) and the lesser the cooling effect of the vegetation will be felt (Saxe et al., 2001). This poses a lot of environmental and health risks to the city dwellers. Urban planners, policy makers and ecologists should work towards protection and conservation of the already existing green spaces and even aim to increase tree cover by certain percentages. They should also create numerous patches of green spaces (Mélissa Giguère, 2009; Anjos \& Lopes, 2017) and not single-big greenery patches (Robinson, 2004). Likewise, habitual street tree maintenance will provide an economical approach for urban landscape improvement (Jim, 
2013).

From the study, there were significant differences among the species' performances as a result of their canopy densities shown by LAI (Table 3). Plants species with higher canopy densities have larger surface areas for evapotranspiration (Loughner et al., 2012; Shahidan, 2015; Sodoudi et al., 2018) and providing shade which in turn reduces temperatures to a greater extent compared to trees with less canopy densities. The results also showed a surface temperature difference of $9.1 \%\left(6.4^{\circ} \mathrm{C}\right)$ in the street warmer than the park at $1 \mathrm{pm}$ (Table 4$)$. This shows that materials used to make the surfaces in streets have low albedo and tend to absorb more heat (Voogt, 2002; Anjos \& Lopes, 2017), compared to the natural surfaces in parks (Govindarajulu, 2014) which are also permeable (Chiesura, 2004; Feyisa, 2014; Stewart \& Oke, 2012).

Increasing albedo for construction materials used by architects and construction managers will help reflect a huge amount of radiation instead of absorbing it, including the roofing materials used (Mélissa Giguère, 2009). Narita et al. (2008) propose parking lots should at least be 35\% paved and 65\% vegetated. There was a notable $11 \%(0.3 \mathrm{~m} / \mathrm{s})$ difference in street $\mathrm{WV}$, being higher than that of the park at $1 \mathrm{pm}$ (Table 4). This is because streets tend to have high wind velocities from the moving vehicles and also as a result of the street canyon effect caused by the adjacent tall buildings on each side of the street (Pauleit, 2003; Narita et al., 2008). On the other hand, parks are mostly open and wind velocity is equally distributed and neutral as a result of having trees which act as wind breakers (Chiesura, 2004; Feyisa, 2014).

Minimizing damages caused by trees to construction and pavements is achievable through development of a proper planting design. Some factors to be considered during installation include the crown height and width, the utility clearance as well as the size of the planting pit. Besides the aesthetics and functionality of the plants, considering the urban trees' architectural aspect is essential in regulating microclimate in Nairobi. Avoiding tree species having drooping branches, weak trunks or having thorns is imperative for safety purposes. To avoid damaging the roads or surrounding pavements, the use of root barriers and root trainers is essential. Moreover, the trees should be planted approximately six meters away from any building. On open spaces with poor soil or compacted surfaces, using various tree planters can be an ideal alternative.

Urban landscape planners and designers of Nairobi city should consider tree species with strong trunks, spreading canopies as well as rounded canopy forms, such as Tipuana tipu tree species. Similarly, evergreen trees with more foliar densities similar to Terminalia mantaly, but with raised crowns are suitable for microclimate regulation. For Nairobi city's streetscapes, some of the trees that were not informed by the study include the Ficus benjamina species. This is because of its invasive nature in terms of canopy and root overgrowth, which is not favorable near construction. However, they can be used in the urban parks and green spaces away from any infrastructure. Generally, a habitual maintenance of 
the existing urban trees is vital in reducing structural failures and their potential hazardous risks.

\section{Conclusion}

From this study, we found out that plants with dense canopies and low SVF reduce temperatures more than plants with less dense canopies. Temperatures in open built and paved areas within Nairobi city are higher than the temperatures in green spaces and they highly contribute to the UHI effects felt by the city dwellers. Nairobi city residents are more likely to suffer no thermal stress in parks, but will experience warm moderate heat stress in built areas during hot seasons. There is therefore need to increase greenery especially evergreen tree species with dense foliage crowns, as well as spreading, rounded and vase canopy forms within the urban open spaces. This will help regulate climatic factors and enhance the thermal comfort of the city's inhabitants. Additionally, during plant selection, Nairobi's landscape planners should consider native tree species that are resistant to the unfavorable urban environmental conditions. Such measures should be used to influence relevant policies within the local government and to sensitize other stakeholders with interests in the urban environment and greening of Nairobi city.

\section{Acknowledgements}

This study was supported by ER-Africa (LOCLIM-3 Project) through NRF-Kenya. We thank Nairobi City County through the Department of Environment for issuing us with permits to conduct the surveys. We are also grateful to the staff of JKUAT and Freie University Berlin (FUB) who assisted in survey campaigns.

\section{Conflicts of Interest}

The authors declare no conflicts of interest regarding the publication of this paper.

\section{References}

Akbari, H., Pomerantz, M., \& Taha, H. (2001). Cool Surfaces and Shade Trees to Reduce Energy Use and Improve Air Quality in Urban Areas. Solar Energy, 70, 95-150. https://doi.org/10.1016/S0038-092X(00)00089-X

Anjos, M., \& Lopes, A. (2017). Urban Heat Island and Park Cool Island Intensities in the Coastal City of Aracaju, North-Eastern Brazil. Sustainability (Switzerland), 9, 1379. https://doi.org/10.3390/su9081379

Atkinson, L. J., Hellicar, M. A., Fitter, A. H., \& Atkin, O. (2007). Impact of Temperature on the Relationship between Respiration and Nitrogen Concentration in Roots: An Analysis of Scaling Relationships, Q10 Values and Thermal Acclimation Ratios. New Phytologist, 173, 110-120. https://doi.org/10.1111/j.1469-8137.2006.01891.x

Bellard, C. (2012). Impacts of Climate Change on the Future of Biodiversity. Ecology Letters, 15, 365-377. https://doi.org/10.1111/j.1461-0248.2011.01736.x

Bosco, N. J., Geoffrey, M. M., \& Kariuki, N. N. (2011). Assessment of Landscape Change 
and Occurrence at Watershed Level in City of Nairobi. African Journal of Environmental Science and Technology, 5, 873-883.

Brattebo, B., \& Booth, B. D. (2003). Long-Term Storm Water Quantity and Quality Performance of Permeable Pavement Systems. Water Research, 37, 4369-4376. https://doi.org/10.1016/S0043-1354(03)00410-X

Cater, M., Dammann, I., Derome, J., Greve, M., \& Leuchner, M. (2009). Leaf Area Index (LAI). In Field Protocol on Radiation Measurements and Leaf Area Index (LAI) (Vol. 3, pp. 1-14). Aachen: RWTH University. http://www.futmon.org/field protocol radiation lai d2 3f.pdf

CCN (2007). City of Nairobi Environment Outlook. Nairobi: City Council of Nairobi, United Nations Environment Programme and the United Nations Centre for Human Settlement.

https://na.unep.net/atlas/kenya/downloads/chapters/Kenya Screen Chapter5-End.pdf

Chandler, T. J. (1962). London's Urban Climate. The Geographical Journal, 128, 279-298. https://doi.org/10.2307/1794042

Chapman, L., \& Thrones, J. E. (2004). Real-Time Sky-View Factor Calculation and Approximation. Atmospheric and Oceanic Technology, 21, 730-741. https://doi.org/10.1175/1520-0426(2004)021<0730:RSFCAA >2.0.CO;2

Chen, L., Ng, E., An, X., Ren, C., Lee, M., Wang, U., \& He, Z. (2012). Sky View Factor Analysis of Street Canyons and Its Implications for Daytime Intra-Urban Air Temperature Differentials in High-Rise, High-Density Urban Areas of Hong Kong: A GISBased Simulation Approach. International Journal of Climatology, 32, 121-136. https://doi.org/10.1002/joc.2243

Chiesura, A. (2004). The Role of Urban Parks for the Sustainable City. Landscape and Urban Planning, 68, 129-138. https://doi.org/10.1016/j.landurbplan.2003.08.003

Deb, C., \& Alur, R. (2010). The Significance of Physiological Equivalent Temperature (PET) in Outdoor Thermal Comfort Studies. International Journal of Engineering Sciences and Technology, 2, 2825-2828.

Elnabawi, M. H., \& Hamza, N. (2019). Behavioural Perspectives of Outdoor Thermal Comfort in Urban Areas: A Critical Review. Atmosphere.

https://doi.org/10.3390/atmos11010051

English, P., Fitzsimmons, K., Hoshiko, S., Margolis, H., McKone, T. E., Rotkin-Ellman, M., \& Ross, Z. (2007). Public Health Impacts of Climate Change in California: Community Vulnerability Assessments and Adaptation Strategies; Heat-Related Illness and Mortality. Salt Lake City. https://ehib.org/wp-content/uploads/2020/06/Heat Vulnerability 2007.pdf

Fahmy, M., Sharples, S., \& Yahiya, M. (2010). LAI Based Trees Selection for Mid-Latitude Urban Developments: A Microclimatic Study in Cairo, Egypt. Building and Environment, 45, 345-357. https://doi.org/10.1016/j.buildenv.2009.06.014

Feyisa, G. L. (2014). Efficiency of Parks in Mitigating Urban Heat Island Effects; Example of Addis Ababa. Landscape and Urban Planning, 123, 87-95. https://doi.org/10.1016/j.landurbplan.2013.12.008

Frazer, L. (2005). Paving Paradise: The Peril of Impervious Surface. Environmental Health Perspectives, 113, 456-462. https://doi.org/10.1289/ehp.113-a456

Georgi, N. J., \& Zafiriadis, K. (2006). The Impact of Park Trees on Microclimate in Urban Areas. Urban Ecosystems, 9, 195-209. https://doi.org/10.1007/s11252-006-8590-9

Govindarajulu, D. (2014). Urban Green Space Planning for Climate Adaptation in Indian Cities. Urban Climate, 10, 2006-2008. https://doi.org/10.1016/j.uclim.2014.09.006 
Jim, C. Y. (2013). Sustainable Urban Greening Strategies for Compact Cities in Developing and Developed Economies. Urban Ecosystem, 16, 741-761. https://doi.org/10.1007/s11252-012-0268-x

Kenya Bureau of Statistics (2019). National Census: Population by County and Sub-County. http://housingfinanceafrica.org/app/uploads/VOLUME-I-KPHC-2019.pdf

Kenya Meteorological Department KMD (2018). In Nairobi Climate. Nairobi: Ministry of Environment and Natural Resources. https://www.meteo.go.ke/index.php?q=report

Klingberg, J., Konarska, J., Lindberg, F., Thorsson, S., \& Klingberg, J. (2015). Measured and Modelled Leaf Area of Urban Woodlands, Parks and Trees in Gothenburg, Sweden. 9th International Conference on Urban Climate Jointly with 12th Symposium on the Urban Environment, Gothenburg, 14 June 2015, 1-6. http://www.meteo.fr/icuc9/LongAbstracts/ucp11-6-1881174 a.pdf

Leuzinger, S., Vogt, R., \& Körner, C. (2010). Tree Surface Temperature in an Urban Environment. Agricultural and Forest Meteorology, 150, 56-62. https://doi.org/10.1016/j.agrformet.2009.08.006

Lin, H., Chen, Y., Zhang, H., Fu, P., Fan, Z., \& Lin, H. (2017). Stronger Cooling Effects of Transpiration and Leaf Physical Traits of Plants from a Hot Dry Habitat than from a Hot Wet Habitat. Functional Ecology, British Ecological Society, 31, 2202-2211. https://doi.org/10.1111/1365-2435.12923

Loughner, C. P., Zhang, D. J. A. and D.-L., Pickering, K. E., Dickerson, R. R., \& Landry, L. (2012). Roles of Urban Tree Canopy and Buildings in Urban Heat Island Effects: Parameterization and Preliminary Results. Applied Meteorology and Climatology, 51, 1775-1793. https://doi.org/10.1175/JAMC-D-11-0228.1

Matzarakis, A., \& Amelung, B. (2008). Physiological Equivalent Temperature as Indicator for Impacts of Climate Change on Thermal Comfort of Humans. Seasonal Forecasts, Climate Change and Human Health, 30, 161-172. https://doi.org/10.1007/978-1-4020-6877-5 10

Matzarakis, A., \& Mayer, H. (1997). Heat Stress in Greece. International Journal of Biometeorology, 41, 34-39. https://doi.org/10.1007/s004840050051

Matzarakis, A., Rutz, F., \& Mayer, H. (2009). Modelling Radiation Fluxes in Simple and Complex Environments: Basics of the RayMan Model. International Journal of Biometeorology, 54, 131-139. https://doi.org/10.1007/s00484-009-0261-0

Mélissa Giguère, M. E. (2009). Urban Heat Island Mitigation Strategies. https://www.inspq.qc.ca/pdf/publications/1513 UrbanHeatIslandMitigationStrategies. pdf

Middel, A., Lukasczyk, J., Maciejewski, R., Demuzere, M., \& Roth, M. (2018). Sky View Factor Footprints for Urban Climate Modeling. Urban Climate, 25, 120-134. https://doi.org/10.1016/j.uclim.2018.05.004

Morris, R. J. (2010). Anthropogenic Impacts on Tropical Forest Biodiversity: A Network Structure and Ecosystem Functioning Perspective. Philosophical Transactions of the Royal Society, 365, 3709-3718. https://doi.org/10.1098/rstb.2010.0273

Narita, K., Sugawara, H., \& Honjo, T. (2008). Effects of Roadside Trees on the Thermal Environment within a Street Canyon. Geographical Reports of Tokyo Metropolitan University, 43, 41-48.

Park, M., Hagishima, A., Tanimoto, J., \& Narita, K. I. (2012). Effect of Urban Vegetation on Outdoor Thermal Environment: Field Measurement at a Scale Model Site. Building and Environment, 56, 38-46. https://doi.org/10.1016/j.buildenv.2012.02.015

Pauleit, S. (2003). Urban Street Tree Plantings: Identifying the Key Requirements. Pro- 
ceedings of the Institution of Civil Engineers-Municipal Engineer, 156, 43-50. https://doi.org/10.1680/muen.2003.156.1.43

Ren, Y. (2011). Relationship between Vegetation Carbon Storage and Urbanization; Case Study of Xiamen China. Forest Ecology and Management, 261, 1214-1223. https://doi.org/10.1016/j.foreco.2010.12.038

Robinson, N. (2004). Spatial Characteristics of Plants. The Planting Design Handbook. https://regwickings.files.wordpress.com/2013/09/planting-design-handbook.pdf

Rossi, F., Castellani, B., Presciutti, A., Morini, E., Filipponi, M., Nicolini, A., \& Santamouris, M. (2015). Retroreflective Façades for Urban Heat Island Mitigation: Experimental Investigation and Energy Evaluations. Applied Energy, 145, 8-20. https://doi.org/10.1016/j.apenergy.2015.01.129

Rushton, B. T. (2001). Low-Impact Parking Lot Design Reduces Runoff and Pollutant Loads. Water Resource Planning and Management, 127, 172-179. https://doi.org/10.1061/(ASCE)0733-9496(2001)127:3(172)

Santamouris, M., Haddad, S., Fiorito, F., Osmond, P., Ding, L., Prasad, D., \& Wang, R. (2017). Urban Heat Island and Overheating Characteristics in Sydney, Australia. An Analysis of Multiyear Measurements. Sustainability, 9, 712.

https://doi.org/10.3390/su9050712

Saxe, H., R., C. M. G., O., J., Ryan, M. G., \& Vourlitis, G. (2001). Tree and Forest Functioning in Response to Global Warming. New Phycologist, 149, 369-400. https://doi.org/10.1046/j.1469-8137.2001.00057.x

Shahidan, M. F. (2015). Potential of Individual and Cluster Tree Cooling Effect Performances through Tree Canopy Density Model Evaluation in Improving Urban Microclimate. Current World Environment, 10, 398-413. https://doi.org/10.12944/CWE.10.2.04

Sodoudi, S., Zhang, H., Chi, X., Müller, F., \& Li, H. (2018). The Influence of Spatial Configuration of Green Areas on Microclimate and Thermal Comfort. Urban Forestry and Urban Greening, 34, 85-96. https://doi.org/10.1016/j.ufug.2018.06.002

Soltani, A., \& Sharifi, E. (2017). Daily Variation of Urban Heat Island Effect and Its Correlations to Urban Greenery: A Case Study of Adelaide. Frontiers of Architectural Research, 6, 529-538. https://doi.org/10.1016/j.foar.2017.08.001

Stewart, I. D., \& Oke, T. R. (2012). Local Climate Zones for Urban Temperature Studies. Bulletin of the American Meteorological Society, 93, 1879-1900. https://doi.org/10.1175/BAMS-D-11-00019.1

Tibaijuka, A. (2007). Nairobi and Its Environment. In Kenya Atlas (pp. 145-161). Nairobi: UN-Habitat. https://na.unep.net/atlas/kenya/downloads/chapters/Kenya Screen Chapter5-End.pdf

Van Hoof, J., Mazej, M., \& Hensen, J. (2010). Thermal Comfort: Research and Practice. Frontiers in Bioscience, 15, 765-788. https://doi.org/10.2741/3645

Voogt, J. A. (2002). Urban Heat Island. In Encyclopedia of Global Environmental Change (Vol. 3, pp. 660-666). Chichester: Wiley.

Welles, J. M., \& Norman, J. M. (2001). Instrument for Indirect Measurement of Canopy Architecture. Agronomy Journal, 83, 818-825.

https://doi.org/10.2134/agronj1991.00021962008300050009x 